\title{
Hubungan Jaringan Komunikasi dan Dinamika Kelompok dengan Kapasitas Petani dalam Agribisnis Padi Organik di Jawa Barat
}

\author{
Correlations of Communication Network and Capacity of Farmers \\ in Organic Rice Agribusiness in West Java
}

\author{
Sri Wahyuni, ${ }^{1}$ Sumardjo, ${ }^{2}$ Djuara P. Lubis, ${ }^{3}$ Dwi Sadono ${ }^{4}$ \\ ${ }^{1}$ Fakultas Pertanian Universitas Andalas, Padang \\ ${ }^{2,3,4}$ Departemen Sains Komunikasi dan Pengembangan Masyarakat, Fakultas Ekologi Manusia, \\ Institut Pertanian Bogor, Bogor
}

\begin{abstract}
Capacity of organic rice farmers in agribusiness is the ability of farmers to implement the organic rice cultivation in accordance with standard certification set by the Institute of Marcetology (IMO) Switzerland. Network communication and group dynamics determine the capacity of farmers in organic rice agribusiness. The study was conducted in Tasikmalaya within groups of Jembar II, Sundamekar, Mekar Karya and Serbaguna II, while in Karawang within groups of Dewi Sri, Wargi Mukti, Benong II and Mindi Lamping. The sample technique is a cluster of random sampling. The method used was survey, data were collected by interview using a questionnaire. Data were analyzed using Pearson correlation. The purposes of this reseacrh to determine the relationship of the communication network and the level of group dynamics on the capacity of organic rice farmers in agribusiness. The results showed that the communication networks in Tasikmalaya and Karawang, both on production and marketing is not related to the capacity of farmers in organic rice agribusiness. Capacity of farmers in Tasikmalaya to identify potential agribusiness and agri-sustaining organic rice is more influenced by group dynamics specifically by group clarity of purposes, group functions and conducive atmosphere of the group. Similarly in Karawang, farmers' capacity to address the problem of agribusiness is more determined by the group dynamics specifically by the group functions, group cohesiveness, conducive atmosphere and targeted group pressures conductive atmosphere.
\end{abstract}

Keywords: capacity of farmers, group dynamics, network communication

\begin{abstract}
Abstrak
Kapasitas petani dalam agribisnis padi organik adalah kemampuan petani untuk menerapkan budidaya padi organik sesuai dengan standar sertifikasi oleh Institute of Marcetology (IMO) Swiss. Jaringan komunikasi dan dinamika kelompok menentukan kapasitas petani dalam agribisnis padi organik. Penelitian ini dilakukan di Tasikmalaya pada kelompok tani Jembar II, Sundamekar, Mekar Karya dan Serbaguna II; sedangkan di Karawang dilakukan pada kelompok tani Dewi Sri, Wargi Mukti, Benong II dan Mindi Lamping. Teknik pengambilan sampel dilakukan secara cluster random sampling. Metode yang digunakan adalah survey, data didapatkan melalui wawancara dengan kuesioner. Analisa data menggunakan korelasi Pearson. Tujuan penelitian ini adalah untuk mengetahui hubungan jaringan komunikasi dan tingkat dinamika kelompok pada kapasitas petani dalam agribisnis padi organik. Hasil penelitian menunjukkan bahwa jaringan komunikasi di Tasikmalaya dan Karawang, baik produksi dan pemasaran tidak berhubungan dengan kapasitas petani dalam agribisnis padi organik. Kapasitas petani di Tasikmalaya dalam mengidentifikasi kapasitas potensi agribisnis dan mempertahankan padi organik lebih banyak dipengaruhi oleh dinamika kelompok terutama oleh kejelasan tujuan, fungsi kelompok, dan suasana kondusif dalam kelompok. Demikian pula di Karawang, kapasitas petani untuk mengatasi masalah agribisnis lebih ditentukan oleh dinamika kelompok terutama oleh fungsi kelompok, kohesifitas kelompok, dan tekanan kelompok yang terarah.
\end{abstract}

Kata kunci: kapasitas petani, dinamika kelompok, jaringan komunikasi

\section{Pendahuluan}

Kondisi petani sampai saat ini masih merupakan tantangan karena dalam melakukan agribisnis petani tidak saja dituntut berorientasi pada produk yang dibutuhkan pasar, tetapi juga harus mampu menciptakan pasar, efisien, dan memiliki daya saing. Petani tidak lagi hanya mengandalkan proteksi dan subsidi pemerintah, mereka dituntut untuk memiliki aspirasi, kreatif, mampu mengambil keputusan yang menguntungkan, inovatif, dan tangguh dalam melakukan agribisnisnya. Dengan kata lain, petani harus memiliki kapasitas dan kemandirian dalam beragribisnis (Sumardjo, 2005)

Kapasitas petani dalam budidaya dan pemasaran mutlak diperlukan dalam agribisnis padi organik. Tamba dan Sarma (2007) menjelaskan bahwa dalam melaksanakan budidaya dan pemasaran petani

${ }^{1}$ Korespondensi penulis 
harus mampu mengidentifikasi potensi yang ada, memanfaatkan peluang agribisnis, mampu mengatasi permasalahan dalam agribinis dan mampu menjaga keberlanjutan agribisnis. Rendahnya kemampuan agribisnis petani selama ini salah satunya disebabkan oleh lemahnya peran dan fungsi kelembagaan, baik lembaga formalmaupun lembaga non formal(Setiawan, 2012). Menurut Syahyuti (2006) dalam menggerakkan agribisnis di pedesaan tidak cukup oleh kelembagaan petani semata, namun dukungan kelembagaan lain turut menentukan keberhasilan agribisnis, setidaknya perlu ada kelembagaan pelaksanaan input budidaya, kelembagaan dalam aktivitas budidaya, kelembagaan pengelolaan hasil pertanian, kelembagaan pemasaran dan kelembagaan pendukung.

Keberadaan kelompok tani sangat terkait dengan kekuatan jaringan komunikasi yang dibangun oleh kelompok petani dengan kelembagaan lainnya (Pakpahan, 2004). Lebih lanjut, Clark (2006) menjelaskan bahwa jaringan dalam suatu organisasi berfungsi untuk mengatur arus informasi, menyatukan orang-orang dengan minat yang sama, membentuk penafsiran yang sama, meningkatkan pengaruh sosial, dan memungkinkan adanya pertukaran sumber daya. McLeod dan Jin-Lee (2012) menyatakan bahwa jaringan sebagai peta koneksi (hubungan) antara semua anggota (node) dalam jaringan kelompok berfungsi untuk menyamakan persepsi dalam kegiatan bersama. Berdasarkan penjelasan di atas penelitian ini bertujuan menganalisis hubungan jaringan komunikasi dengan kapasitas petani dalam agribisnis padi organik dan hubungan dinamika kelompok dengan kapasitas petani dalam agribisnis padi organik.

\section{Metode Penelitian}

Penelitian ini menggunakan metode survey di Kabupaten Tasikmalaya, pada kelompok Jembar II, Sundamekar, Mekar Karya dan kelompok Serbaguna II, dan di Kabupaten Karawang pada kelompok Dewi Sri, Wargi Mukti, Benong II dan kelompok Mindi Lamping. Unit analisis penelitian adalah petani padi organik, dengan metode sensus. Total responden penelitian adalah 267 orang responden, tersebar 132 orang responden di Kabupaten Tasikmalaya dan 135 orang responden lainnya di Kabupaten Karawang. Penelitian dilakukan dari bulan Februari sampai April 2015. Data primer diperoleh melalui wawancara terstruktur dengan menggunakan kuesioner. Data sekunder diperoleh dari Dinas Pertanian, Penyuluhan. Analisa data untuk hubungan antar variabel menggunakan analisa korelasi Pearson.

\section{Hasil danPembahasan}

\section{Kapasitas Petani dalam Agribisnis Padi Organik}

Kapasitas petani merupakan kemampuan petani dalam budidaya dan pemasaran padi organik. Kemampuan petani dalam budidaya padi organik bisa diperoleh melalui pembinaan kelompok dan pemasaran beras organik bisa dilakukan secara kolektif melalui kerjasama kelompok dengan pihak lain. Kapasitas petani dipengaruhi oleh faktor internal dan faktor eksternal. Faktor internal dipengaruhi karakteristik individu petani dan faktor eksternal dipengaruhi oleh dinamika kelompok dan jaringan komunikasi.

Secara umum kapasitas petani pada kedua kabupaten berbeda nyata dalam hal kemampuan dalam memanfaatkan peluang, mengatasi masalah dan menjaga keberlanjutan agribisnis (Tabel 1). Kapasitas petani di Kabupaten Karawang lebih tinggi dalam memanfaatkan peluang agribisnis dibandingkan dengan Kabupaten Tasikmalaya. Usahatani di Kabupaten Karawang termasuk small independent specialist family farm (McConnell \& Dillon, 1997), artinya petani melakukan perencanaan budidaya sampai pemasaran secara sendiri. Usahatani di Kabupaten Tasikmalaya termasuk small dependent specialist family farm, artinya petani melakukan budidaya padi organik sendiri namun memiliki ketergantungan pemasaran dengan pihak kelompok/perusahaan. Berdasarkan pengamatan di lapangan, di Kabupaten Tasikmalaya hasil budidaya beras organik dikumpulkan oleh ketua kelompok, untuk seterusnya dikirim ke Gapoktan Simpatik untuk proses pengeringan, pengepakan dan ekspor. Hasil budidaya beras organik yang dihasilkan petani di Kabupaten Karawang pada umumnya dijual kepada anggota kelompok yang juga pemilik modal, yang selanjutnya dijual kepada pedagang besar dan perusahaan.

Budidaya padi organik tidak terlepas dari kendala teknis yakni pembibitan, pembuatan pupuk kompos, pestisida nabati dan pembuatan MOL. Kemampuan petani di Kabupaten Tasikmalaya dalam menyediakan sarana budidaya padi organik lebih tinggi dibandingkan dengan petani di Kabupaten Karawang. Petani di Kabupaten Tasikmalaya mampu secara mandiri menangani masalah-masalah dalam budidaya padi organik. Hal ini didukung oleh kemampuan petani dalam memanfaatkan limbah rumah tangga dan bahanbahan di lingkungan sekitar petani. Kemampuan petani 
Tabel 1. Kapasitas Petani dalam Agribisnis Padi Organik di Kabupaten Tasikmalaya dan Kabupaten Karawang

\begin{tabular}{llcccc}
\hline \multicolumn{1}{c}{ Peubah/Indikator } & Kategori & & $\mathbf{\%}$ & \\
\cline { 1 - 4 } Kapasitas Petani dalam & & $\begin{array}{c}\text { Tasikmalaya } \\
\mathbf{n = 1 3 2}\end{array}$ & $\begin{array}{c}\text { Karawang } \\
\mathbf{n = 1 3 5}\end{array}$ & $\begin{array}{c}\text { Total } \\
\mathbf{n}=\mathbf{2 6 7}\end{array}$ & Uji Beda \\
\hline Mengibisnis Padi Organik & & 25,7 & 31,8 & 28,7 & 0,579 \\
Memanfifikasi Potensi Agribisnis & Rendah & 74,3 & 68,2 & 71,3 & \\
& Tinggi & 80,3 & 18,5 & 49,4 & $0,000^{* *}$ \\
Mengatasi Permasalahan Agribisnis Peluang Agribisnis & Rendah & 19,7 & 81,5 & 50,6 & \\
& Tinggi & 29,5 & 50,3 & 39,9 & $0,000^{* *}$ \\
Menjaga Keberlanjutan Agribisnis & Rendah & 70,5 & 49,7 & 60,1 & \\
& Tinggi & 20,4 & 56,3 & 38,4 & $0,000^{* *}$ \\
& Rendah & 79,6 & 43,7 & 61,6 & \\
\hline
\end{tabular}

Keterangan: $\quad *$ signifikan pada taraf 0,01

** signifikan pada taraf 0,05

dalam mengatasi masalah budidaya dan pemasaran juga didukung oleh fungsi kontrol yang dilakukan kelompok. Secara berkala petugas teknis dan petugas Internal Control System (ICS) melakukan kunjungan ke kelompok petani guna membantu petani mengatasi masalah dalam budidaya padi organik dan pemasaran. Hasil penelitian Prayoga (2010) menyatakan bahwa petani padi organik yang memiliki pengalaman lebih dari lima tahun dan rutin mengikuti kegiatan penyuluhan memiliki tingkat efisiensi teknis, sehingga petani padi organik mempunyai peluang meningkatkan produksinya sekitar 30\%.

Keberlanjutan agribisnis merupakan kemampuan petani dalam menjaga kualitas dan standar sertifikasi organik. Petani di Kabupaten Tasikmalaya mempunyai kemampuan yang tinggi dalam menjaga keberlanjutan agribisnis dibandingkan petani di Kabupaten Karawang. Berdasarkan keadaan di lapangan petani di Kabupaten Tasikmalaya mempunyai kemampuan dan komitmen lebih tinggi dalam menjaga keberlanjutan agribisnis beras organik, dengan cara memfilter air yang akan dialirkan ke sawah menggunakan eceng gondok, membuat pupuk organik dengan pemanfaatan limbah rumah tangga dan membuat pestisida nabati secara mandiri. Secara umum petani di Kabupaten Tasikmalaya dituntut menjaga keberlanjutan agribisnis dengan cara melakukan budidaya padi organik sesuai dengan standar sertifikasi organik yang telah ditetapkan oleh Insitute of Marketology (IMO). Hal ini sejalan dengan petani padi organik di Desa Sukorejo yang konsisten dalam menerapkan padi organik di Jawa Tengah, bahkan Desa Sukorejo memberikan kontribusi terbesar dalam ekspor beras organik di Jawa Tengah (Jumna, 2015).

\section{Hubungan Jaringan Komunikasi dengan Kapasitas Petani dalam Agribisnis Padi Organik}

Kapasitas petani salah satunya dipengaruhi oleh faktor eksternal yakni jaringan komunikasi. Kemampuan petani dalam budidaya padi organik dan pemasaran tidak terlepas dari interaksi petani dengan petani lainnya di dalam kelompok dan di luar kelompok. Derajat keterhubungan individu dengan individu lainnya serta jumlah hubungan maksimal yang mampu dibuat individu akan menentukan kemampuan individu dalam budidaya padi organik dan pemasaran.

\section{Hubungan Sentralitas Lokal dengan Kapasitas Petani}

Sentralitas lokal menunjukkan banyaknya jumlah individu yang terhubung dengan petani padi organik lain sehingga petani padi organik yang memiliki ikatan/hubungan yang banyak dapat dikategorikan sebagai petani padi organik yang aktif dalam mencari informasi dan menyebarkan informasi serta memungkinkan dirinya menjadi pusat informasi (star) dalam jaringan budidaya dan pemasaran di kelompoknya. Hal ini karena banyak individu lain yang menghubungi dan dihubunginya, bahkan petani padi organik tersebut dapat menjadi sumber informasi karena banyak memperoleh pengetahuan (informasi) hasil interaksi dengan berbagai pihak. Tingkat hubungan seseorang dengan banyak individu lain memungkinkan terjadinya proses pertukaran informasi dalam peristiwa komunikasi yang jauh lebih sering dibandingkan dengan orang yang hanya berhubungan dengan sedikit individu. Menurut Riyanto et al., (2015) Ketua kelompok sebagai pusat informasi (star) memiliki kemampuan komunikasi dan kerjasama 
Tabel 2. Nilai Koefisien Korelasi Pearson Jaringan Komunikasi (Sentralitas Lokal) dengan Kapasitas Petani dalam Agribisnis Padi Organik

\begin{tabular}{|c|c|c|c|c|c|c|c|c|c|}
\hline \multirow[t]{2}{*}{ No } & \multirow[t]{2}{*}{$\begin{array}{c}\text { Jaringan } \\
\text { Komunikasi }\end{array}$} & \multicolumn{2}{|c|}{$\begin{array}{c}\text { Identifikasi Potensi } \\
\text { Agribisnis }\end{array}$} & \multicolumn{2}{|c|}{$\begin{array}{c}\text { Pemanfaatan } \\
\text { Peluang Agribisnis }\end{array}$} & \multicolumn{2}{|c|}{$\begin{array}{c}\text { Mengatasi Masalah } \\
\text { Agribisnis }\end{array}$} & \multicolumn{2}{|c|}{$\begin{array}{c}\text { Menjaga } \\
\text { Keberlanjutan } \\
\text { Agribisnis }\end{array}$} \\
\hline & & Tasik & Karawang & Tasik & Karawang & Tasik & Karawang & Tasik & Karawang \\
\hline 1 & $\begin{array}{l}\text { Sentralitas } \\
\text { Lokal } \\
\text { mengenai } \\
\text { budidaya }\end{array}$ & 0,004 & $-0,256^{* *}$ & $-0,471^{* *}$ & $-0,474^{* *}$ & $-0,254^{* *}$ & $-0,483^{* *}$ & $-0,037$ & $-0,220^{*}$ \\
\hline 2 & $\begin{array}{l}\text { Sentralitas } \\
\text { Lokal } \\
\text { mengenai } \\
\text { pemasaran }\end{array}$ & $-0,121$ & $-0,154$ & $-0,434^{* *}$ & $-0,335 * *$ & $-0,030$ & $-0,472^{* *}$ & $-0,104$ & $-0,148$ \\
\hline
\end{tabular}

Keterangan : * berhubungan nyata pada $\mathrm{P}<0,05$ dan **berhubungan nyata pada $\mathrm{P}<0,01$

dengan berbagai sektor, hal ini merupakan modal utama dalam pembangunan pertanian berkelanjutan.

Hubungan sentralitas lokal dengan kapasitas petani yang diteliti adalah mengenai budidaya dan pemasaran. Hasil uji korelasi Pearson pada Tabel 2, menjelaskan bahwa terdapat hubungan nyata bernilai negatif antara sentralitas lokal mengenai budidaya dengan kapasitas petani dalam memanfaatkan peluang dan mengatasi masalah dalam agribisnis di Kabupaten Tasikmalaya, dengan nilai koefisien korelasi adalah $-0,471^{* *}$ dan $-0,254 * *$, artinya semakin banyak petani memiliki ikatan/hubungan dengan petani padi organik lain atau terhubung dengan berbagai sumber informasi maka semakin rendah kapasitas dalam agribisnis. Hal ini disebabkan karena aktor yang berperan dalam budidaya adalah anggota petani yang memiliki kemampuan dalam budidaya padi organik tetapi rendah dalam kemampuan agribisnis.

Terdapat hubungan nyata bernilai negatif antara sentralitas lokal mengenai budidaya dengan kapasitas petani dalam memanfaatkan peluang, mengatasi masalah, dan menjaga keberlanjutan agribisnis padi organik di Kabupaten Karawang, dengan nilai koefisien korelasi adalah $-0,256^{* *},-0,474^{* *}$ dan $-0,220^{*}$, artinya semakin banyak petani memiliki ikatan/hubungan dengan petani padi organik lain atau terhubung dengan berbagai sumber informasi maka semakin rendah kapasitas dalam agribisnis. Hal ini disebabkan karena ketua kelompok sebagai aktor sentral hanya berperan dalam budidaya dan tidak berperan dalam kegiatan agribisnis.

Terdapat hubungan nyata bernilai negatif antara sentralitas lokal mengenai pemasaran dengan kapasitas petani dalam pemanfaatan peluang agribisnis baik di Kabupaten Tasikmalaya maupun di Kabupaten
Karawang, dengan koefisien korelasi adalah $-0,434^{* *}$ dan $-0,335^{* *}$. Artinya semakin banyak petani padi organik memiliki ikatan/hubungan dengan petani padi organik lain atau terhubungkan dengan berbagai sumber informasi maka semakin rendah kemampuannya dalam agribisnis. Hal ini disebabkan karena aktor yang berperan dalam pemasaran di Kabupaten Tasikmalaya adalah ketua kelompok dan di Kabupaten Karawang adalah anggota kelompok. Ketua kelompok hanya sebagai koordinator pengumpul hasil budidaya petani dan anggota kelompok hanya sebagai pedagang pengumpul/tengkulak.

Frekuensi pertukaran informasi yang dialami oleh seseorang dalam proses komunikasi menjadikan seseorang memiliki pengetahuan dalam kegiatan budidaya dan pemasaran sehingga semakin sering petani padi organik melakukan pertukaran informasi budidaya dan pemasaran padi organik di dalam system akan semakin banyak informasi yang ia terima, sehingga semakin tinggi pengetahuannya dalam budidaya padi organik. Oleh karena itu petani padi organik yang memiliki ikatan hubungan dengan banyak individu terutama sumber informasi akan mempunyai pengetahuan yang memadai tentang budidaya dan pemasaran padi organik.

\section{Hubungan Sentralitas Global dengan Kapasitas Petani}

Sentralitas global merupakan derajat yang menunjukkan banyaknya jalur yang harus dilalui oleh individu tertentu untuk menghubungi semua individu di dalam lingkungannya. Derajat ini menunjukkan kemampuan individu untuk dapat menghubungi semua individu lain dalam lingkungannya. Derajat sentralitas 
Tabel 3. Nilai Koefisien Korelasi Pearson Jaringan Komunikasi (Sentralitas Global) dengan Kapasitas Petani dalam Agribisnis Padi Organik

\begin{tabular}{|c|c|c|c|c|c|c|c|c|c|}
\hline \multirow[t]{2}{*}{ No } & \multirow[t]{2}{*}{$\begin{array}{l}\text { Jaringan } \\
\text { Komunikasi }\end{array}$} & \multicolumn{2}{|c|}{$\begin{array}{c}\text { Identifikasi Potensi } \\
\text { Agribisnis }\end{array}$} & \multicolumn{2}{|c|}{$\begin{array}{c}\text { Pemanfaatan } \\
\text { Peluang Agribisnis }\end{array}$} & \multicolumn{2}{|c|}{$\begin{array}{c}\text { Mengatasi Masalah } \\
\text { Agribisnis }\end{array}$} & \multicolumn{2}{|c|}{$\begin{array}{c}\text { Menjaga } \\
\text { Keberlanjutan } \\
\text { Agribisnis }\end{array}$} \\
\hline & & Tasik & Karawang & Tasik & Karawang & Tasik & Karawang & Tasik & Karawang \\
\hline 1 & $\begin{array}{l}\text { Sentralitas } \\
\text { Global } \\
\text { mengenai } \\
\text { produksi }\end{array}$ & $-0,192^{*}$ & $-0,469^{* *}$ & $-0,545^{* *}$ & $-0,408^{* *}$ & $-0,333^{* *}$ & $-0,147$ & $-0,122$ & $-0,670^{* *}$ \\
\hline 2 & $\begin{array}{l}\text { Sentralitas } \\
\text { Global } \\
\text { mengenai } \\
\text { pemasaran }\end{array}$ & $-0,266^{* *}$ & $-0,497^{* *}$ & $-0,496^{* *}$ & $-0,344^{* *}$ & $-0,340^{* *}$ & $-0,012$ & $-0,166$ & $-0,414^{* *}$ \\
\hline
\end{tabular}

Keterangan : * berhubungan nyata pada $\mathrm{P}<0,05$ dan **berhubungan nyata pada $\mathrm{P}<0,01$

global dapat memberikan petunjuk mengenai siapasiapa saja di dalam sebuah lingkungan yang dapat menjadi kunci penyebar informasi. Selanjutnya, hubungan antara sentralitas global dengan kapasitas petani dalam agribisnis padi organik dapat dilihat pada Tabel 3.

Tabel 3 memperlihatkan bahwa di Kabupaten Tasikmalaya terdapat hubungan yang sangat nyata dan negatif antara sentralitas global mengenai budidaya dan pemasaran dengan kapasitas petani dalam mengidentifikasi potensi agribisnis, memanfaatkan peluang agribisnis dan kemampuan mengatasi masalah agribisnis. Hal ini berarti semakin singkat jarak yang ditempuh oleh petani padi organik dalam melakukan komunikasi dengan individu lainnya maka semakin tinggi kemampuan petani dalam agribisnis padi organik. Hal ini disebabkan karena orang yang berperan pada sentralitas lokal merupakan orang yang sama berperan pada sentralitas global. Menurut Malinick et al., (2013) seseorang yang menjadi pusat dalam jaringan komunikasi memiliki kendali atas aliran dan transmisi informasi. Hal ini bisa dipengaruhi oleh faktor internal seperti daya tarik yang kharismatik, popularitas, tingkat keterlibatan secara keseluruhan dalam pergerakan jaringan dan tanggung jawab yang diemban.

Terdapat hubungan sangat nyata dan negatif antara sentralitas global mengenai budidaya dan pemasaran dengan kapasitas petani dalam agribisnis padi organik di Kabupaten Karawang. Hal ini berarti semakin singkat jarak yang ditempuh oleh petani padi organik dalam melakukan komunikasi mengenai budidaya dan pemasaran dengan individu lainnya maka semakin tinggi kemampuan dalam agribisnis padi organik.
Sentralitas global merupakan derajat kemampuan individu untuk mengakses seluruh anggota jaringan. Dalam arti lain, semakin singkat jarak yang dilalui petani padi organik tersebut untuk menghubungi seluruh petani padi organik lainnya dalam lingkungan, maka semakin tinggi kemampuan dalam budidaya dan pemasaran padi organik. Sentralitas global merupakan kemampuan konektivitas individu dengan individu lain dalam satuan lingkungan tertentu sehingga dapat berperan sebagai kunci penyebar informasi. Individu yang berperan sebagai kunci penyebar informasi adalah orang yang memiliki keberdayaan informasi yang dapat disebarluaskan kepada individu lain.

\section{Kebersamaan (Betweeness)}

Kebersamaan merupakan posisi individu tertentu terletak di antara individu-individu lain pada suatu jaringan, di mana posisi tersebut menunjukkan kemampuannya untuk menjalin hubungan dengan klik atau kelompok lain dalam suatu jaringan. Jika seseorang berada dalam suatu jalur komunikasi yang menghubungkan antar individu atau klik maka individu tersebut memiliki posisi yang sentral.

Individu dengan nilai kebersamaan tinggi mempunyai potensi kendali komunikasi yang dapat memainkan potensi sebagai broker atau gatekeeper dalam suatu jaringan. Individu lain akan menjadi tergantung kepadanya jika jalur yang menghubungkan dengan orang lain harus melewati individu tersebut.

Tabel 4 menunjukkan bahwa tidak terdapat hubungan antara kapasitas petani dalam agribisnis padi organik dengan kebersamaan (betweeness) baik pada budidaya maupun pada pemasaran. Petani di Kabupaten Tasikmalaya memiliki kapasitas yang tinggi 
Tabel 4. Nilai Koefisien Korelasi Pearson Jaringan Komunikasi (betweeness) dengan Kapasitas Petani dalam Agribisnis Padi Organik

\begin{tabular}{|c|c|c|c|c|c|c|c|c|c|}
\hline \multirow[t]{2}{*}{ No } & \multirow[t]{2}{*}{$\begin{array}{c}\text { Jaringan } \\
\text { Komunikasi }\end{array}$} & \multicolumn{2}{|c|}{$\begin{array}{c}\text { Identifikasi } \\
\text { Potensi Agribisnis }\end{array}$} & \multicolumn{2}{|c|}{$\begin{array}{c}\text { Pemanfaatan } \\
\text { Peluang Agribisnis }\end{array}$} & \multicolumn{2}{|c|}{$\begin{array}{c}\text { Mengatasi } \\
\text { Masalah } \\
\text { Agribisnis }\end{array}$} & \multicolumn{2}{|c|}{$\begin{array}{c}\text { Menjaga } \\
\text { Keberlanjutan } \\
\text { Agribisnis }\end{array}$} \\
\hline & & Tasik & Karawang & Tasik & Karawang & Tasik & Karawang & Tasik & Karawang \\
\hline 1 & $\begin{array}{l}\text { Betweeness } \\
\text { mengenai budidaya }\end{array}$ & $-0,003$ & $-0,061$ & $-0,049$ & $-0,007$ & $-0,098$ & $-0,168$ & 0,100 & 0,011 \\
\hline 2 & $\begin{array}{l}\text { Betweeness } \\
\text { mengenai } \\
\text { pemasaran }\end{array}$ & 0,016 & $-0,061$ & $-0,134$ & $-0,079$ & 0,038 & $-0,076$ & $-0,042$ & 0,024 \\
\hline
\end{tabular}

Keterangan : * berhubungan nyata pada $\mathrm{P}<0,05$ dan **berhubungan nyata pada $\mathrm{P}<0,01$

dalam mengidentifikasi potensi agribisnis, mengatasi masalah agribisnis dan mampu menjaga keberlanjutan agribisnis. Sebaliknya petani di Kabupaten Karawang memiliki kapasitas dalam mengidentifikasi potensi agribisnis dan juga mampu memanfaatkan peluang agribisnis. Rendahnyakemampuan petani di Kabupaten Tasikmalaya dalam memanfaatkan peluang agribisnis, karena kegiatan agribisnis dikelola oleh Gapoktan Simpatik.

Individu yang memiliki nilai betweeness maksimum pada budidaya di Kabupaten Tasikmalaya diperankan oleh anggota kelompok, sedangkan pada pemasaran diperankan oleh ketua kelompok. Sebaliknya, di Kabupaten Karawang, nilai maksimum untuk kebersamaan mengenai budidaya diperankan oleh ketua kelompok, sedangkan untuk pemasaran diperankan oleh anggota kelompok yang juga berprofesi sebagai pedagang pengumpul. Hal ini mengindikasikan bahwa anggota kelompok di Kabupaten Tasikmalaya berperan sebagai broker atau gatekeeper mengenai budidaya. Hal ini berarti anggota kelompok tersebut memiliki kemampuan untuk membuat hubungan dan menjadi penghubung dengan berbagai pihak. Sementara di Kabupaten Karawang posisi sebagai broker/gatekeeper mengenai budidaya diperankan oleh ketua kelompok yang notabene merupakan ketua kelompok sekaligus ketua gapoktan dan juga sebagai petani teladan. Individu tersebut memiliki kemampuan untuk membuat hubungan dan menjadi penghubung dengan pihak lainnya, seperti Dinas Pertanian, Penyuluh pemerintah dan penyuluh swadaya.

Individu yang memiliki nilai betweeness maksimum pada pemasaran di Kabupaten Tasikmalaya diperankan oleh ketua kelompok, broker/gatekeeper yang memiliki kemampuan untuk membuat hubungan dan menjadi penghubung antara anggota kelompok dengan gapoktan. Ketua kelompok merupakan salah satu pengurus bidang pembelian di Gapoktan Simpatik, sehingga hal ini mempermudah koordinasi di lapangan. Sebaliknya, di Kabupaten Karawang nilai kebersamaan maksimum diperankan oleh anggota kelompok, artinya anggota kelompok berperan sebagai broker/gatekeeper. Ini menandakan bahwa ketua kelompok mampu membuat hubungan dan menjadi penghubung antara penjual dan pembeli. Berkembangnya tengkulak-tengkulak di Kabupaten Karawang menyebabkan kegiatan agribisnis padi organik tidak bisa diselenggarakan oleh Gapoktan Dewi Sri.

\section{Hubungan Jaringan Komunikasi dengan Dinamika Kelompok}

Jaringan komunikasi yang diuji dengan variabel dinamika kelompok adalah sentralitas lokal, sentralitas global dan betweeness, baik pada budidaya maupun pemasaran. Sentralitas lokal mengenai budidaya di Kabupaten Tasikmalaya berhubungan sangat nyata dan positif dengan tujuan kelompok dan fungsi kelompok. Hal ini disebabkan karena petani di Kabupaten Tasikmalaya saling berinteraksi dengan petani yang lain dalam menjalankan fungsi kontrol terhadap pelaksanaan standar sertifikasi organik. Artinya semakin tinggi ikatan hubungan komunikasi yang dibuat oleh petani dalam lingkungan terdekatnya, maka semakin jelas tujuan yang akan dicapai dan semakin berjalan fungsi kontrol terhadap pelaksanaan standar sertifikasi organik.

Sentralitas lokal mengenai pemasaran berhubungan nyata dan positif dengan tujuan kelompok, fungsi kelompok dan tekanan kelompok. Artinya, semakin tinggi ikatan hubungan komunikasi yang dibuat oleh petani padi organik dalam lingkungan terdekatnya, maka semakin jelas tujuan yang akan dicapai, berjalannya fungsi kontrol terhadap 
pelaksanaan standar sertifikasi organik serta adanya tekanan dalam mencapai tujuan bersama. Sentralitas lokal mengenai pemasaran diperankan oleh ketua kelompok, sehingga ketua kelompok memotivasi anggotanya dalam mencapai tujuan kelompok yakni peningkatan budidaya padi organik, mengontrol langsung pelaksanaan budidaya padi organik yang sesuai dengan standar serta memberikan tekanan berupa reward dan punishment bagi anggota.

Sentralitas global mengenai budidaya berhubungan nyata dan positif terhadap tujuan kelompok dan fungsi kelompok. Artinya, semakin pendek "distance" yang harus dilalui petani untuk menghubungi semua individu dalam kelompoknya, maka semakin jelas tujuan kelompok dan fungsi kontrol terhadap kelompok. Hal ini dikarenakan melalui jarak yang pendek petani bisa mengontak petani lain terkait budidaya, sehingga tercapai tujuan budidaya dan fungsi kontrol terhadap budidaya padi organik. Sentralitas global mengenai pemasaran juga berhubungan nyata dan positif dengan tujuan kelompok dan tekanan kelompok. Artinya semakin pendek "distance" yang harus dilalui petani dalam pemasaran padi organik, maka semakin tercapai tujuan yang ditargetkan dalam pemasaran. Hasil pengamatan di lapangan menunjukkan bahwa ketua kelompok memegang peran sentral dalam pemasaran beras organik, sehingga ketua kelompok mengontrol langsung hasil budidaya padi organik serta mengumpulkan hasil budidaya untuk selanjutnya diolah di Gapoktan Simpatik yang memiliki Rice Milling Unit (RMU) serta proses packing yang sesuai standar sertifikasi.

Berdasarkan Tabel 5 memperlihatkan bahwa di Kabupaten Karawang, sentralitas lokal mengenai pemasaran berhubungan nyata dan negatif terhadap dinamika kelompok. Artinya, semakin rendah

Tabel 5. Nilai Koefisien Korelasi Pearson antara Jaringan Komunikasi dengan Dinamika Kelompok.

\begin{tabular}{|c|c|c|c|c|c|c|c|c|c|}
\hline \multirow{2}{*}{ No } & \multirow{2}{*}{$\begin{array}{c}\text { Jaringan } \\
\text { Komunikasi }\end{array}$} & \multicolumn{8}{|c|}{ Dinamika Kelompok } \\
\hline & & Tujuan & Struktur & Fungsi & Bina & Kompk & Suana & Teknan & Efektf \\
\hline \multicolumn{10}{|c|}{ Kabupaten Tasikmalaya } \\
\hline 1 & $\begin{array}{l}\text { Sentralitas Lokal } \\
\text { Budidaya }\end{array}$ & $0,228 * *$ & 0,089 & $0,243 * *$ & 0,090 & 0,084 & 0,081 & 0,139 & $-0,002$ \\
\hline 2 & $\begin{array}{l}\text { Sentralitas Lokal } \\
\text { Pemasran }\end{array}$ & $0,203^{*}$ & 0,059 & $0,178^{*}$ & 0,145 & 0,080 & 0,084 & $0,172^{*}$ & 0,035 \\
\hline 3 & $\begin{array}{l}\text { Sentralitas Global } \\
\text { Budidaya }\end{array}$ & $0,239 * *$ & 0,111 & $0,186^{*}$ & 0,142 & 0,086 & 0,076 & $-0,241 * *$ & 0,055 \\
\hline 4 & $\begin{array}{l}\text { Sentralitas Global } \\
\text { Pemasaran }\end{array}$ & $0,175^{*}$ & 0,090 & 0,124 & 0,160 & 0,083 & 0,032 & $0,260 * *$ & 0,140 \\
\hline 5 & $\begin{array}{l}\text { Betweeness } \\
\text { Budidaya }\end{array}$ & 0,004 & 0,087 & 0,033 & 0,036 & 0,032 & 0,107 & $-0,008$ & 0,002 \\
\hline 6 & $\begin{array}{l}\text { Betweeness } \\
\text { Pemasaran }\end{array}$ & 0,099 & 0,101 & 0,057 & 0,083 & 0,117 & 0,155 & 0,031 & $-0,029$ \\
\hline \multicolumn{10}{|c|}{ Kabupaten Karawang } \\
\hline 1 & $\begin{array}{l}\text { Sentralitas Lokal } \\
\text { Budidaya }\end{array}$ & $-0,087$ & $-0,002$ & $-0,148$ & $-0,064$ & $-0,023$ & $-0,148$ & $-0,113$ & $-0,120$ \\
\hline 2 & $\begin{array}{l}\text { Sentralitas Lokal } \\
\text { Pemasran }\end{array}$ & $-0,251 * *$ & $-0,252 * *$ & $-0,282 * *$ & $-0,175^{*}$ & $-0,157$ & $-0,193 *$ & $-0,234 * *$ & $-0,176^{*}$ \\
\hline 3 & $\begin{array}{l}\text { Sentralitas Global } \\
\text { Budidaya }\end{array}$ & 0,134 & $0,310^{* *}$ & 0,154 & $0,219^{*}$ & $0,391 * *$ & 0,150 & $0,171^{*}$ & 0,032 \\
\hline 4 & $\begin{array}{l}\text { Sentralitas Global } \\
\text { Pemasaran }\end{array}$ & $-0,251 * *$ & $-0,252 * *$ & $-0,282 * *$ & $-0,175^{*}$ & $-0,157$ & $-0,193 *$ & $-0,235^{* *}$ & $-0,176^{*}$ \\
\hline 5 & $\begin{array}{l}\text { Betweeness } \\
\text { Budidaya }\end{array}$ & $-0,122$ & $-0,156$ & $-0,199 *$ & $-0,282 * *$ & $-0,081$ & $-0,016$ & $-0,125$ & $-0,093$ \\
\hline 6 & $\begin{array}{l}\text { Betweeness } \\
\text { Pemasaran }\end{array}$ & $-0,028$ & $-0,055$ & $-0,023$ & $-0,148$ & $-0,058$ & 0,073 & $-0,039$ & $-0,087$ \\
\hline
\end{tabular}


ikatan hubungan yang dibuat oleh individu petani dengan lingkungan terdekatnya, maka semakin rendah kedinamisan kelompok. Hal ini disebabkan karena sentralitas lokal pemasaran diperankan oleh anggota kelompok yang berprofesi sebagai pedagang pengumpul/tengkulak, tidak ada standar sertifikasi yang dicapai oleh petani.

Sentralitas global mengenai budidaya berhubungan nyata dan positif terhadap struktur kelompok, pembinaan kelompok, kekompakkan kelompok dan tekanan kelompok. Artinya semakin pendek "distance" yang harus dilalui petani dalam budidaya, maka semakin dinamis kelompok tersebut. Hal ini disebabkan karena sentralitas global dalam budidaya di Kabupaten Karawang diperankan oleh ketua kelompok yang senantiasa mendinamiskan kelompok melalui pembinaan anggota kelompok, kekompakkan kelompok dan tekanan kelompok. Ketua kelompok membina, menjaga kekompakkan kelompok dengan cara memberi pelatihan tentang cara membuat MOL, pestisida nabati dan pembibitan. Namun tidak semua yang diberikan ketua kelompok dijalankan oleh anggota kelompok.

Sentralitas global mengenai pemasaran berhubungan nyata dan negatif dengan dinamika kelompok. Artinya semakin pendek "distance" yang harus dilalui individu untuk menghubungi individu lain dalam pemasaran, maka kedinamisan kelompok menjadi rendah. Hal ini disebabkan karena sentralitas global diperankan oleh anggota kelompok yang berprofesi sebagai tengkulak, yang tidak memikirkan kedinamisan kelompok tapi lebih memikirkan keuntungan dirinya.

Kebersamaan (betweeness) sendiri membahas mengenai budidaya berhubungan nyata dan negatif dengan fungsi kelompok dan pembinaan kelompok. Artinya semakin tinggi kemampuan seseorang mengendalikan komunikasi mengenai budidaya, maka semakin rendah kemampuannya melaksanakan fungsi kontrol terhadap pelaksanaan standar'sertifikasi organik dan pembinaan budidaya padi organik. Hasil pengamatan di lapangan menunjukkan bahwa kendali komunikasi mengenai budidaya diperankan oleh ketua kelompok, namun ketua kelompok tidak bisa mengontrol anggotanya dalam memenuhi standar sertifikasi dan tidak bisa memaksa anggotanya melaksanakan budidaya padi organik. Hal ini disebabkan karena tidak ada kesepakatan bersama, serta tidak ada kerjasama dengan pihak lain yang mengharuskan anggota memenuhi standar sertifikasi organik.

\section{Hubungan Dinamika Kelompok dengan Kapasitas Petani dalam Agribisnis Padi Organik}

Dinamika kelompok merupakan kekuatankekuatan di dalam kelompok yang menentukan perilaku kelompok dan perilaku anggota kelompok untuk tercapainya tujuan kelompok. Menurut Slamet (1978) untuk menilai kekuatan-kekuatan di dalam kelompok perlu diperhatikan unsur dinamika kelompok yaitu: (a) tujuan kelompok, (b) struktur kelompok, (c) fungsi tugas, (d) pembinaan kelompok, (e) kekompakkan kelompok, (f) suasana kelompok, (g) tekanan kelompok, dan (h) keefektifan kelompok.

Berdasarkan hasil penelitian dapat dilihat bahwa tujuan kelompok berkorelasi sangat nyata dan positif dengan kapasitas petani dalam menjaga keberlanjutan agribisnis padi organik. Hal ini berarti semakin jelas tujuan kelompok maka semakin tinggi kapasitas petani dalam menjaga keberlanjutan agribisnis. Gapoktan Simpatik sebagai wadah bagi pengembangan agribisnis padi organik di Kabupaten Tasikmalaya telah menetapkan agribisnis sebagai tujuan bersama anggota. Hal ini berimplikasi terhadap pendapatan anggota yang meningkat, karna harga beras organik dinilai lebih tinggi oleh pihak eksportir.

Untuk itu petani sebagai anggota kelompok dituntut untuk menjaga keberlanjutan kegiatan agribisnis dengan cara melakukan budidaya padi organik sesuai standar sertifikasi yang telah ditetapkan oleh Institute of Marcetology (IMO) Swiss. Selama petani konsekuen dengan kegiatan agribisnis yang merupakan tujuan dari kelompok, serta menjalankan budidaya dengan baik dan benar, maka akan tercapai keberlanjutan agribisnis padi organik.

Terdapat korelasi nyata dan positif antara fungsi kelompok dengan kapasitas petani dalam mengidentifikasi potensi agribisnis dan menjaga keberlanjutan agribisnis. Hal ini berarti semakin berjalan fungsi kelompok sebagai kontrol terhadap anggota kelompok, maka semakin meningkat kemampuan petani dalam mengidentifikasi potensi agribisnis dan menjaga keberlanjutan agribisnis padi organik. Gapoktan simpatik melalui petugas Internal Kontrol System (ICS) melakukan bimbingan kepada kelompok petani, dengan cara kunjungan satu kali sebulan secara bergilir kepada masing-masing kelompok binaan gapoktan simpatik. Dengan demikian, petani padi organik menyadari bahwa budidaya padi organik yang mereka lakukan dikontrol dengan baik untuk menjaga kualitas mutu padi organik, dengan demikian agribisnis padi organik bisa terus berlanjut. Kontrol 
yang dilakukan oleh petugas ICS dilakukan sesuai dengan Standar Operasional Prosedur (SOP), jika terdapat ketidaksesuaian pelaksanaan budidaya padi organik dengan standar sertifikasi, maka bisa saja terjadi pemutusan hubungan kerjasama dengan petani bersangkutan. Damanik (2013) mengemukakan bahwa unsur-unsur yang paling kuat mempengaruhi dinamika kelompok adalah fungsi tugas diikuti secara berturut-turut oleh suasana kelompok, kekompakkan kelompok, pembinaan kelompok, keefektifan kelompok dan suasana kelompok. Untuk itu fungsi kontrol yang dilakukan petugas ICS sangat penting guna mengontrol kelangsungan budidaya padi organik sesuai standar sertifikasi. Adapun hubungan dinamika kelompok dengan kapasitas petani dalam agribisnis padi organik dapat dilihat pada Tabel 6 .

Suasana kelompok berhubungan nyata dan positif dengan kapasitas petani dalam menjaga keberlanjutan agribisnis. Hal ini berarti semakin kondusif suasana kelompok maka semakin meningkat kemampuan anggota kelompok dalam menjaga keberlanjutan agribisnis. Hasil pengamatan di lapangan ditemukan suasana kelompok yang kondusif antara petani dengan sesama petani, maupun petani dengan petugas ICS, penyuluh dan Dinas Pertanian. Semua berbaur menjadi satu dan terjadi interaksi yang sewajarnya tanpa ada tekanan. Suasana yang kondusif tersebut telahmemacupetaniuntuk melakukan kegiatan budidaya padi organik sesuai standar sertifikasi, seperti penggunaan air harus disaring dari bahan bahan kimia dengan menggunakan eceng gondok, pembuatan pupuk organik dengan memanfaatkan limbah pertanian dan limbah rumah tangga, penggunaan pestisida nabati jika terjadi serangan hama dan sebagainya. Hal ini merupakan upaya yang dilakukan anggota dalam menjaga keberlanjutan kegiatan agribisnis.

Terdapat hubungan sangat nyata dan positif antara fungsi kelompok, kekompakkan kelompok, suasana kelompok dan tekanan kelompok dengan kapasitas petani dalam mengatasi masalah agribisnis. Hal ini berarti masalah agribisnis bisa diatasi dengan berjalannya fungsi kelompok sebagai kontrol, kompaknya anggota kelompok, suasana kelompok yang kondusif dan tekanan kelompok yang rendah. Gapoktan Dewi Sri sebagai wadah bagi petani memiliki peran strategis dalam mengatasi masalah budidaya padi organik yang dianggap sulit dan memberatkan bagi petani. Melalui fungsi kelompok dipraktekkan pembuatan pupuk organik, MOL, pestisida nabati. Hal ini dimaksudkan untuk membantu petani mengatasi masalah dalam pertanian organik. Namun keadaan di lapangan memperlihatkan bahwa pelaksanaan

Tabel 6. Koefisien Korelasi Pearson antara Dinamika Kelompok dengan Kapasitas Petani dalam Agribisnis Padi Organik

\begin{tabular}{|c|c|c|c|c|c|c|c|c|c|}
\hline \multirow[t]{2}{*}{ No } & \multirow[t]{2}{*}{$\begin{array}{l}\text { Dinamika } \\
\text { Kelompok }\end{array}$} & \multicolumn{2}{|c|}{$\begin{array}{c}\text { Identifikasi Potensi } \\
\text { Agribisnis }\end{array}$} & \multicolumn{2}{|c|}{$\begin{array}{c}\text { Pemanfaatan } \\
\text { Peluang Agribisnis }\end{array}$} & \multicolumn{2}{|c|}{$\begin{array}{c}\text { Mengatasi Masalah } \\
\text { Agribisnis }\end{array}$} & \multicolumn{2}{|c|}{$\begin{array}{c}\text { Menjaga } \\
\text { Keberlanjutan } \\
\text { Agribisnis }\end{array}$} \\
\hline & & Tasik & Karawang & Tasik & Karawang & Tasik & Karawang & Tasik & Karawang \\
\hline 1 & $\begin{array}{l}\text { Tujuan } \\
\text { Kelompok }\end{array}$ & 0,125 & 0,039 & $-0,105$ & 0,054 & $-0,239^{* *}$ & 0,056 & $0,231^{* *}$ & $-0,038$ \\
\hline 2 & $\begin{array}{l}\text { Struktur } \\
\text { Kelompok }\end{array}$ & 0,111 & $-0,116$ & $-0,241^{* *}$ & $-0,119$ & $-0,161$ & 0,015 & 0,157 & $-0,135$ \\
\hline 3 & $\begin{array}{l}\text { Fungsi } \\
\text { Kelompok }\end{array}$ & $0,197^{*}$ & 0,039 & $-0,043$ & $-0,008$ & $-0,308^{* *}$ & $0,205^{*}$ & $0,252^{* *}$ & $-0,081$ \\
\hline 4 & $\begin{array}{l}\text { Pembinaan } \\
\text { Kelompok }\end{array}$ & $-0,124$ & 0,097 & 0,055 & $-0,115$ & $-0,243^{* *}$ & 0,084 & $-0,097$ & $-0,056$ \\
\hline 5 & $\begin{array}{l}\text { Kekompakan } \\
\text { Kelompok }\end{array}$ & $-0,186^{*}$ & 0,032 & 0,009 & $-0,003$ & $-0,223^{*}$ & $0,252^{* *}$ & 0,121 & $-0,101$ \\
\hline 6 & $\begin{array}{l}\text { Suasana } \\
\text { Kelompok }\end{array}$ & $-0,222^{*}$ & $-0,056$ & 0,103 & $-0,140$ & $-0,090$ & $0,217^{*}$ & $0,193^{*}$ & $-0,192^{*}$ \\
\hline 7 & $\begin{array}{l}\text { Tekanan } \\
\text { Kelompok }\end{array}$ & $-0,171^{*}$ & 0,002 & $-0,171^{*}$ & $-0,111$ & $-0,003$ & $0,249^{* *}$ & $-0,303^{* *}$ & $-0,034$ \\
\hline 8 & $\begin{array}{l}\text { Efektivitas } \\
\text { Kelompok }\end{array}$ & $-0,325^{* *}$ & 0,077 & 0,101 & 0,119 & $-0,260^{* *}$ & 0,130 & 0,105 & $-0,124$ \\
\hline
\end{tabular}


budidaya padi organik tidak dilaksanakan sesuai standar sertifikasi karena masih banyak dijumpai pemakaian bahan-bahan kimia. Di samping itu, gapoktan Dewi Sri belum memperoleh sertifikasi organik dan tidak melakukan kegiatan agribisnis, sehingga motivasi anggota menjadi rendah dalam budidaya padi organik.

\section{Hubungan Karakteristik Petani, Ketersediaan Informasi dan Dukungan Kelembagaan Pendukung terhadap Kapasitas Petani dalam Agribisnis Padi Organik}

Kapasitas petani dalam agribisnis padi organik tidak saja ditentukan oleh jaringan komunikasi, tetapi lebih ditentukan oleh dinamika kelompok. Karakteritik petani di Kabupaten Tasikmalaya yakni pengalaman petani dalam budidaya padi organik turut menentukan kapasitas petani dalam memanfaatkan peluang agribisnis. Indeks korelasi antara pengalaman petani dalam budidaya padi organik dengan kapasitas petani dalam memanfaatkan peluang agribisnis adalah $-0,343^{* *}$ ini berarti semakin tinggi pengalaman yang dimiliki petani dalam budidaya padi organik, maka semakin meningkat kemampuan petani dalam memanfaatkan peluang agribisnis. Petani yang memiliki pengalaman dalam budidaya padi organik menyadari bahwa budidaya padi organik lebih mudah dan lebih murah, sehingga mereka konsisten melaksanakan budidaya padi organik dan konsisten menjalin kerjasama dengan pihak eksportir.

Ketersediaan informasi mengenai budidaya padi organik di Kabupaten Karawang, memiliki hubungan nyata dan positif dengan kapasitas petani dalam mengatasi masalah agribisnis. Indeks korelasi antara relevansi informasi dan kelengkapan informasi dengan kemampuan petani dalam mengatasi masalah agribisnis adalah $0,217^{*}$ dan $0,194^{*}$. Ini berarti semakin relevan dan lengkap informasi yang diterima petani tentang budidaya padi organik maka semakin meningkat kemampuan petani dalam mengatasi masalah agribisnis padi organik. Adapun masalah yang sering dihadapi petani di Kabupaten Karawang adalah masalah hama tikus dan sulitnya membawa pupuk organik ke tengah sawah dengan hamparan yang luas, sehingga petani menjalankan budidaya padi semi organik. Menurut Fuady et al., (2012) perilaku petani dalam mencari dan menyebarkan informasi pertanian organik lebih efektif dengan menggunakan komunikasi interpersonal dibandingkan dengan dengan komunikasi bermedia, sehingga jaringan komunikasi yang dibangun di dalam kelompok menjadi penting untuk menyebarkan informasi dengan sesama.

Ketajaman informasi mengenai budidaya padi organik di Kabupaten Tasikmalaya berhubungan sangat nyata dan positif dengan kapasitas petani menjaga keberlanjutan agribisnis, dengan indeks Pearson $0,289^{* *}$. Ini berarti semakin tajam/detail informasi yang diperoleh petani dalam budidaya padi organik maka semakin meningkat kemampuan petani dalam menjaga kualitas dan mutu padi organik demi keberlanjutan agribisnis. Selanjutnya keterwakilan informasi berhubungan sangat nyata dan positif dengan kapasitas petani dalam memanfaatkan peluang agribisnis, dengan indeks korelasi Pearson adalah $0,265^{* *}$. Ini berarti semakin banyak informasi atau informasi yang diterima petani sudah memenuhi keinginan dan kebutuhannya maka semakin meningkat kemampuan petani dalam memanfaatkan peluang agribisnis.

Dukungan dinas pertanian berhubungan nyata danpositifdengankeberlanjutanagribisnis diKabupaten Tasikmalaya, dengan indeks korelasi Pearson adalah $0,290^{* *}$. Ini berarti semakin tinggi dukungan dinas pertanian maka semakin meningkat kemampuan petani dalam menjaga keberlanjutan agribisnis. Dukungan yang diberikan oleh Dinas Pertanian di Kabupaten Tasikmalaya berupa kemudahan ijin ekspor beras organik, dengan demikian anggota kelompok menjaga keberlanjutan ekspor tersebut dengan melakukan budidaya padi organik sesuai standar sertifikasi.

Dukungan Dinas Pertanian di Kabupaten Karawang berhubungan nyata dan positif dengan kapasitas petani dalam memanfaatkan peluang agribisnis padi organik, dengan indeks korelasi Pearson $0,340^{* *}$. Ini berarti semakin tinggi dukungan dinas pertanian dalam menyelenggarakan kegiatan pelatihan budidaya padi organik, maka semakin terbuka peluang agribisnis bagi petani. Dukungan LSM juga berhubungan nyata dan positif dengan kemampuan petani mengidientifikasi potensi agribisnis dan memanfaatkan peluang agribisnis, dengan indeks korelasi Pearson adalah $0,256^{* *}$ dan $0,245^{* *}$. Ini berarti semakin tinggi dukungan LSM maka akan meningkatkan kemampuan petani dalam menggali potensi agribisnis dan pemanfaatan peluang agribisnis. Namun keadaan di Kabupaten Karawang belum ada LSM yang menjalin kerjasama dengan Gapoktan Dewi Sri, sehingga petani secara perorangan melakukan kegiatan penjualan sendiri. Demikian pula dukungan koperasi yang berhubungan nyata dan positif dengan kapasitas petani dalam mengidientifikasi potensi agribisnis dan kapasitas dalam memanfaatkan 
peluang agribisnis, dengan indeks korelasi $0,436^{* *}$ dan $0,404^{* *}$. Ini berarti semakin tinggi dukungan koperasi maka semakin meningkat kemampuan petani dalam menggali potensi dan memanfaatkan peluang agribisnis. Namun keadaan dilapangan menunjukkan bahwa dukungan koperasi rendah, sehingga rendah pula kemampuan petani dalam menggali potensi dan memanfaatkan peluang.

\section{Kesimpulan}

Kapasitas petani dalam agribisnis padi organik, baik pada budidaya maupun pada pemasaran di kedua kabupaten tidak dipengaruhi oleh jaringan komunikasi, namun lebih ditentukan oleh dinamika kelompok. Unsur-unsur dinamika kelompok yang berhubungan dengan kapasitas petani dalam mengidentifikasi potensi agribisnis dan kapasitas dalam menjaga keberlanjutan agribisnis di Kabupaten Tasikmalaya lebih ditentukan oleh adanya kejelasan tujuan kelompok, berjalannya fungsi kontrol terhadap kelompok, dan suasana yang kondusif. Di Kabupaten Karawang unsur dinamika kelompok yang berhubungan dengan kapasitas petani dalam mengatasi masalah agribisnis adalah berjalannya fungsi kelompok dalam pembinaan, adanya kekompakkan kelompok, suasana kelompok yang kondusif serta adanya tekanan kelompok yang terarah.

Kapasitas petani di Kabupaten Tasikmalaya yaknikapasitas dalammemanfaatkanpeluang agribisnis ditentukan oleh pengalaman petani dalam budidaya padi organik dan keterwakilan informasi. Ketajaman informasi mengenai budidaya padi organik dan dukungan dinas pertanian menentukan kapasitas petani dalam menjaga keberlanjutan agribisnis. Kapasitas petani di Kabupaten Karawang yakni kapasitas dalam mengidentifikasi agribisnis ditentukan oleh dukungan LSM, kapasitas petani dalam memanfaatkan peluang agribisnis ditentukan oleh dukungan dinas pertanian, kapasitas petani dalam mengatasi masalah agribisnis lebih ditentukan oleh relevansi dan kelengkapan informasi budidaya padi organik.

\section{Daftar Pustaka}

Damanik IPN. 2013. Faktor-faktor yang Mempengaruhi Dinamika Kelompok dan Hubungannya dengan Kelas Kemampuan Kelompok Petani di Desa Pulokencana Kabupaten Serang. Jurnal Penyuluhan. 9(1):31-40.

Fuady I, Lubis DP, Lumintang RWE. 2012. Perilaku
Komunikasi Petani dalam Pencarian Informasi Pertanian Organik (Kasus Petani Bawang Merah di Desa Srigading Kabupaten Bantul). Jurnal Komunikasi Pembangunan. 10(2): 10-18.

Jumna BK. 2015. Strategi Pengembangan Usahatani dalam Upaya Peningkatan Produksi Padi Organik di Kecamatan Sambirejo Kabupaten Sragen Development Analysis Journal. 4(3): 256-264.

Malinick TE, Tindall DB, Mario D. 2013. Network Centrality and Social Movement Media Coverage: A two-mode network analytic approach. Social Network. 35 (2013) 148: 10.1016/j. socnet.2011.10.005.

McConnell DJ, Dillon JL. 1997. Farm Management for Asia: a System Approach. Department of Agricultural and Resources Economics. Australia (AU):University of New South Sales.

McLeodJ,JinLN. 2012 Social Networks, Public Discussion and Civic Engagement: a Socialization Perspective. New York (US): SAGE Publication Inc.

Pakpahan A. 2004. Mengapa Kita Tertinggal? Karena Kita Lalai akan Dinamika dan Kekuatan Rakyat. Majalah Analisis Kebijakan Pertanian (Agricultural Policy Analysis). Bogor (ID): Pusat Penelitian dan Pengembangan Sosial Ekonomi Pertanian.

Prayoga A. 2010. Produktivitas dan Efisiensi Teknis Usahatani Padi Organik Lahan Sawah. Jurnal Agro Ekonomi 28(1): 1-19.

Riyanto, Hermawan Sutisari S. 2015. Kerjasama Antar Sektor dalam Program Pertanian Padi Organik untuk Mewujudkan Pembangunan Berkelanjutan (Sustainable Development). Jurnal Administrasi Publik. 1(4): 128-134.

Setiawan I. 2012. Dinamika Pemberdayaan Petani: Sebuah Refleksi dan Generalisasi Kasus di Jawa Barat. Bandung (ID): Widya Padjadjaran.

Sumardjo. 2005. Pembangunan Sistem dan Usaha Agribisnis: Pengalaman Membangun Jaringan Kerjasama Kemitraan Lumbung Pangan Sebagai Lembaga Penggerak Agribisnis Masyarakat. Pusat Studi Pembangunan Pertanian dan Pedesaan-LPPM IPB. Bogor.

Syahyuti. 2006.30 Konsep Penting dalam Pembangunan Perdesaan: Penjelasan tentang Konsep, Istilah, Teori, Indikator serta Peubah. Jakarta (ID): PT Bina Reka Pariwara.

Tamba M, Sarma M. 2007. Faktor-faktor yang Mempengaruhi Kebutuhan Informasi Pertanian bagi Petani Sayuran di Propinsi Jawa Barat. Jurnal Penyuluhan. 3(1): 24-34. 